\title{
Seismic Paleo-Geomorphic System of the Extensional Province of the Niger Delta: An Example of the Okari Field
}

\author{
Muslim B. Aminu and Moses O. Olorunniwo \\ Additional information is available at the end of the chapter
}

http://dx.doi.org/10.5772/48197

\section{Introduction}

Hydrocarbon exploration and exploitation requires that the spatial and depth distribution and interplay of factors favorable to commercial hydrocarbon accumulation are thoroughly appreciated. These factors include the distribution of source rock, reservoir rock, and migration pathways, the fidelity of sealing mechanisms, and timing, the temporal relatioinship between reservoir rock formation and the expulsion of hydrocarbons from the source rock. The distribution of these elements of the petroleum system is a result of the tectonic history and fill processes occuring in a basin.

As hydrocarbon exploration moves into geologically and economically more challenging environments, such as deeper subsurface locations, deepwater regions, sub-ice in the Artic, and into geologically and stratigraphyically more complex environments, the costs of exploration is bound to be on the rise and the risks associated with field development greater. Continued success in the hunt for Oil and Gas reserves therefore, depends upon a thorough understanding of the subsurface geology of exploration fields, the ability to accurately predict and delineate the spatial and depth distribution of subsurface geologic facies (source rock, reservoir rock and seal) and the ability to discriminate the fluids saturating reservoirs (oil, gas or brine) and possibly quantifying such.

Seismic geomorphology which is the integration of three-dimensional (3-D) seismic data with analytical techniques typically used in the study of Earth land forms, is growing in importance as a tool in understanding the stratigraphy of both mature fields and underdeveloped basins (Dunlap et al, 2010). Seismic geomorphologic analysis allows geoscientists to correctly identify, interpret, and predict the distribution of possible hydrocarbon-bearing deposits. It helps to unravel the major factors which have contributed to and or continue to control the evolution of a basin or field. 
In this study, we implement a series of conventional interpretation procedures and advanced imaging techniques to unravel the paleo-geomorphology, tectonic history and fill architecture of a hydrocarbon target within the Okari Oil Field.

\section{The Niger delta}

The Niger delta is situated in the Gulf of Guinea on the west coast of Central Africa (Figure. 1). It is located in the southern part of Nigeria between latitudes $4^{0} 00^{\prime} \mathrm{N}$ and $6^{0} 00^{\prime} \mathrm{N}$ and longitudes $3^{0} 00^{\prime} \mathrm{N}$ and $9^{0} 00^{\prime} \mathrm{N}$. It is bounded in the south by the Gulf of Guinea (or the $4000 \mathrm{~m}$ bathymetric contour) and in the North by older (Cretaceous) tectonic elements which include the Anambra Basin, Abakaliki uplift and the Afikpo syncline. In the east and west respectivily, the Cameroon volcanic line and the Dahomey Basin mark the bounds of the Delta, Figure 1. The Cenozoic Niger Delta is situated at the intersection of the Benue trough and the South Atlantic Ocean where a triple junction developed during the separation of South America from Africa (Burke, 1972; Whiteman, 1982). The delta is considered one of the most prolific hydrocarbon provinces in the world, and recent giant oil discoveries in the deep-water areas suggest that this region will remain a focus of exploration activities (Corredor et al, 2005).

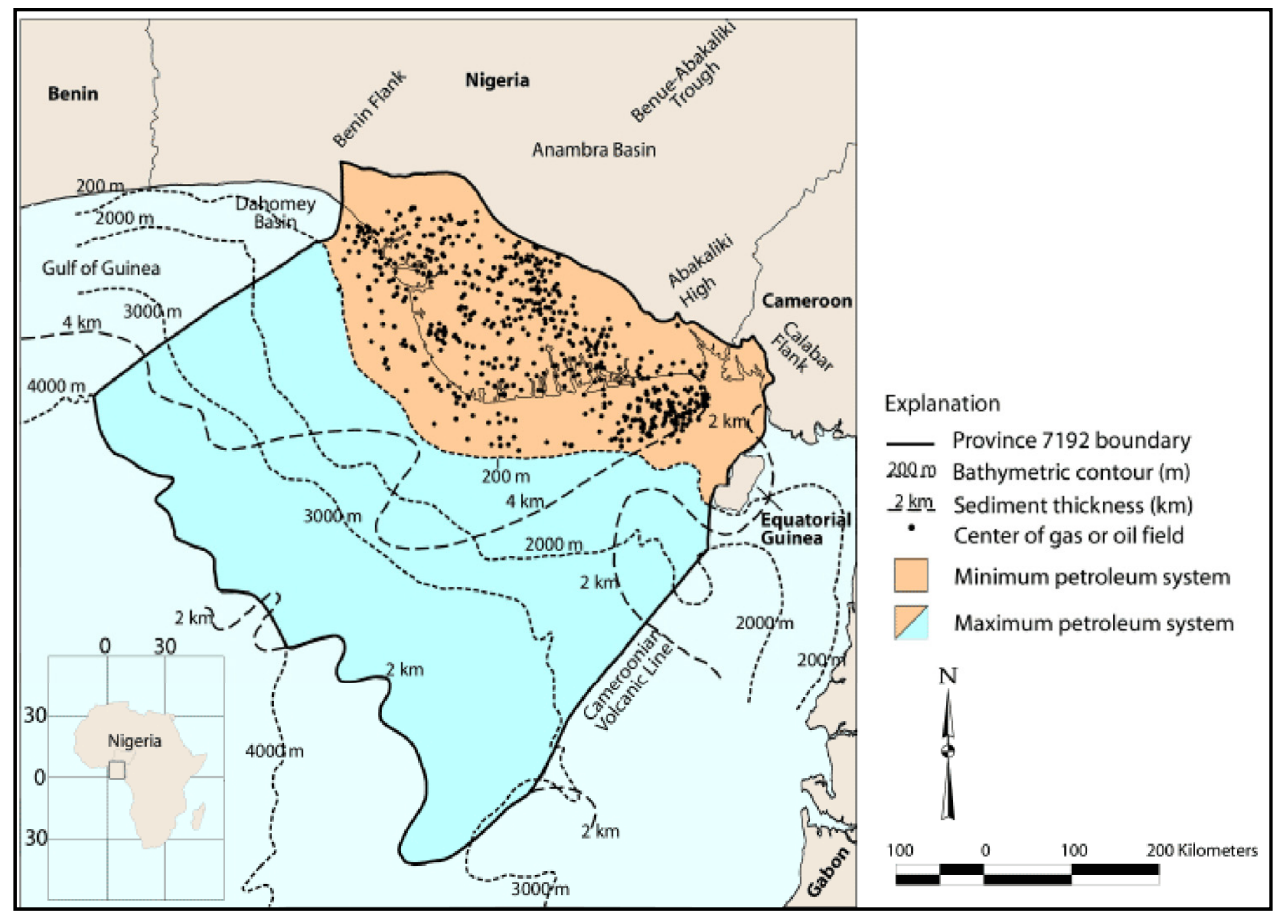

Figure 1. Map of Niger Delta showing province outline (maximum petroleum system); bounding structural features; minimum petroleum system as defined by oil and gas field center points (Modified from Petroconsultants, 1996, as cited in Tuttle et al, 1999). 
Furthermore, the Niger delta is one of the world's largest deltas, with a sub-aerial acreage of about $75,000 \mathrm{~km}^{2}$. It is composed of an overall regressive clastic sequence, which reaches a maximum thickness of 30,000 to $40,000 \mathrm{ft}$ (9000 to $12000 \mathrm{~m}$ ). The development of the delta has been dependent on the balance between the rate of sedimentation and the rate of subsidence (Doust and Omatsola, 1990). This balance and the resulting sedimentary patterns were constrained by the structural configuration and tectonics of the basement (Evamy et al, 1978). Important influences on sedimentary rates have included eustatic sea-level changes and climatic variations in the hinterlands. Subsidence has been controlled largely by initial basement morphology and differential sediment loading of unstable shales (Doust and Omatsola, 1990).

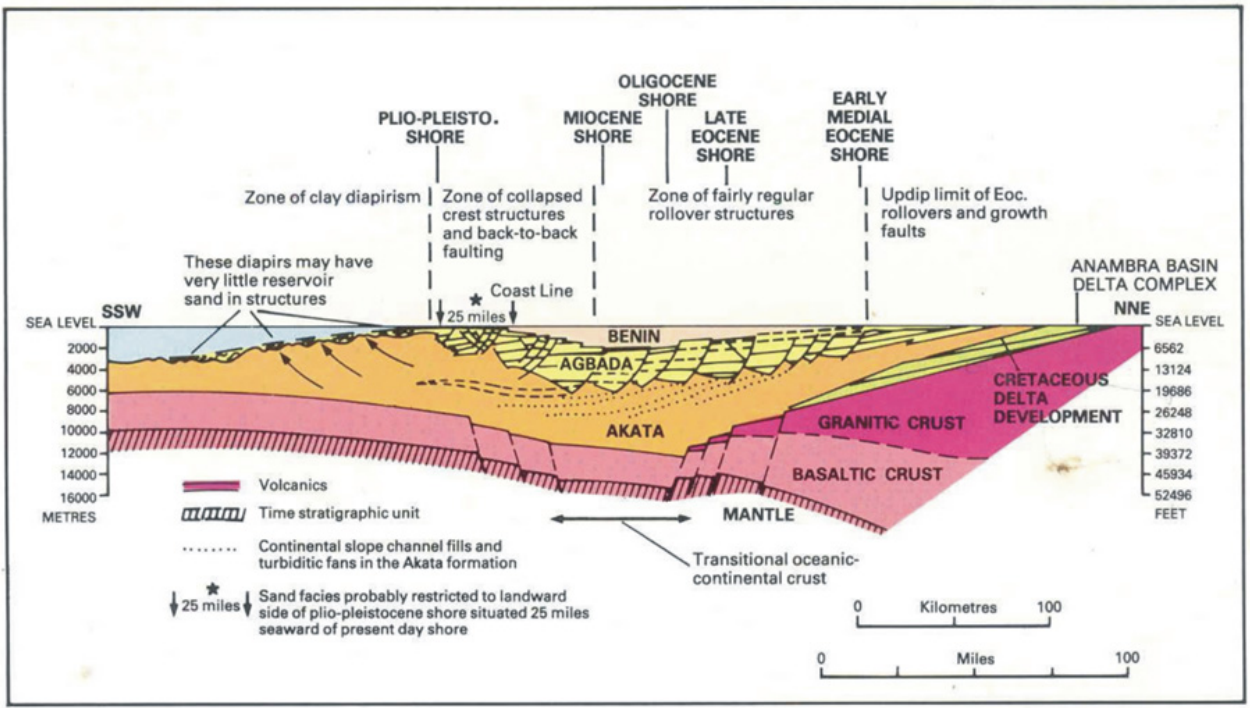

Figure 2. Generalized dip section of the Niger Delta showing the structural provinves of the Delta. The slips resulting from the collapse of shelf sediments in the extentional province is diverted onto thrust ramps through detachemnt structures in the basal Akata formation and comsumed by contractional folds in the deep-water fold and thrust belts (Adapted from Whiteman, 1982).

The Delta has built out over the collapsed continental margin, and its core is located above the collapsed continental margin at the site of the triple junction formed during the middle Cretaceous. The main sediment supply has been provided by an extensive drainage system, which in its lower reaches follows two failed rift arms, the Benue and Bida basins. Sediment input generally has been continuous since the Late Cretaceous, but the regressive record has been interrupted by episodic transgressions, some of considerable extent (Weber and Daukoru, 1975). The Niger delta has prograded into the Gulf of Guinea at a steadily increasing rate in response to the evolving drainage area, basement subsidence and eustatic sea level changes. Initially, the delta prograded over extensionally thinned and collapsed continental crust of the West African margin (Figure 2), as far as the triple junction, filling in the basement graben-and-horst topography (Murat, 1970). During the middle and late 
Eocene, sedimentary rocks became increasingly sandy, marking the onset of a general regression of the deltaic deposition.

Of dominant importance in the development of the delta, as in similar settings elsewhere in the world has been the influence of synsedimentary listric normal faults. These have been forming at least since the Paleocene and define sites of locally increased subsidence and sedimentation. They lie sub-parallel to the paleo-coastline and are presumed to sole out at relatively shallow depths within marine shale sequences. A number of major basin-wide growth fault zones define depositional realms at succeeding periods of delta history (Doust and Omatsola, 1990). In the paralic interval, growth fault associated rollover structures trapped hydrocarbons. Faults in general play an important role in the hydrocarbon distribution. Growth faults may even function as hydrocarbon migration paths from the overpressured marine clays. There is an intimate relationship between structure and stratigraphy. They both depend on the interplay between rates of sediment supply and subsidence (Evamy et al., 1978).

\subsection{Structure}

The Niger Delta is regarded as a classical shale tectonics province ( $\mathrm{Wu}$ and Bally, 2000). The instability and constant motion of the shales in response to the weight of the advancing sediment wedge has resulted in the development of different structural styles in different belts of the Delta.

The Delta has thus been subdivided into five zones. Corredor et al. (2005) identified these structural zones (Figure 3) as [1] an extensional province beneath the continental shelf that is characterized by both basinward-dipping (Roho-type) and counter-regional growth normal faults and associated rollovers and depocenters; [2] a mud diapir zone located beneath the upper continental slope, which is characterized by passive, active, and reactive mud diapirs, including shale ridges and massifs, shale overhangs, vertical mud diapirs that form mud volcanoes at the seafloor, and interdiapir depocenters; [(3] the inner fold and thrust belt, which is characterized by basinward verging thrust faults (typically imbricated) and associated folds, including some detachment folds; [4] a transitional detachment fold zone beneath the lower continental slope that is characterized by large areas of little or no deformation interspersed with large, broad detachment folds above structurally thickened Akata Formation; and [5] the outer fold and thrust belt characterized by both basinward- and hinterland-verging thrust faults and associated folds. The inner and outer fold and thrust belts are most evident in the bathymetry, where ridges represent the crests of fault-related folds, and low regions correspond to piggyback basins formed above the backlimbs of fault imbricates. The inner fold and thrust belt extends in an arcuate path across the center of the offshore delta, whereas the outer fold and thrust belt consists of northern and southern sections that define two outboard lobes of the delta (Corredor et al, 2005). These two lobes, and their associated fold belts, are separated by a major rise in the basement topography that corresponds to the northern culmination of the Charcot fracture zone (Figure 3). The break between the northern and southern sections of the outer fold and 


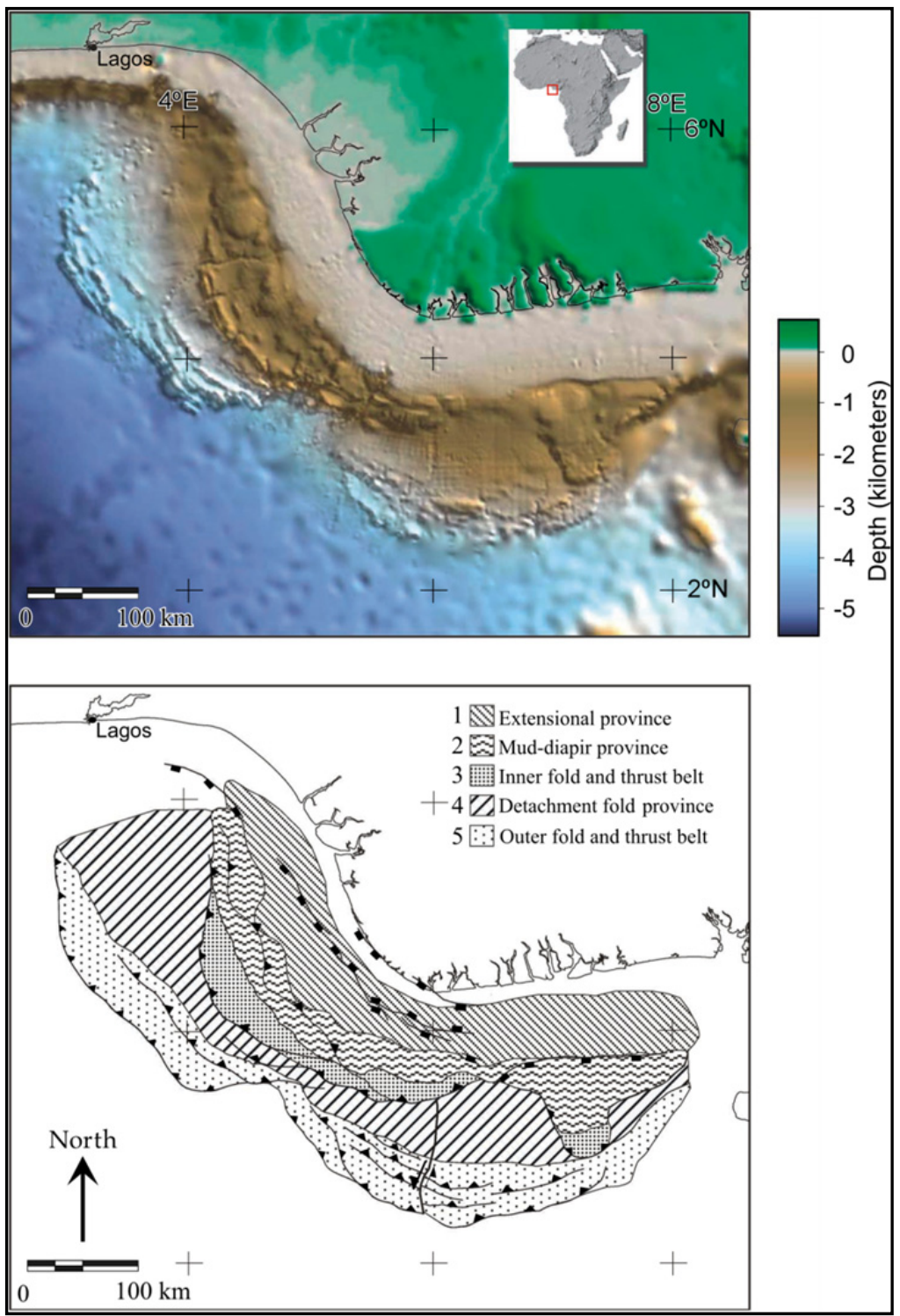

Figure 3. Bathymetric Sea-floor image of the Niger Delta obtained from a dense grid of twodimensional seismic reflection profiles and the global bathymetric database (Smith and Sandwell, 1997, as cited in Corredor et al, 2005), showing the main structural provinces.

thrust belt are the results of thrust sheets being stacked in a narrow zone above and behind this major basement uplift (Connors et al., 1998; Wu and Bally, 2000). Deformation across these structural provinces is active today, resulting in pronounced bathymetry expressions of structures that are not buried by recent sediments, as illustrated in Figure 3 (Corredor et al, 2005). 


\subsection{Stratigraphy}

The lithostratigraphy of the Niger Delta Basin (Figure 4) consists of three main rockstratigraphic units of Cretaceous to Holocene origin (Short and Stauble, 1967; Frankl and Cordry, 1967; Avbovbo, 1978). These units represent the prograding depositional environments (Corredor et al, 2005).

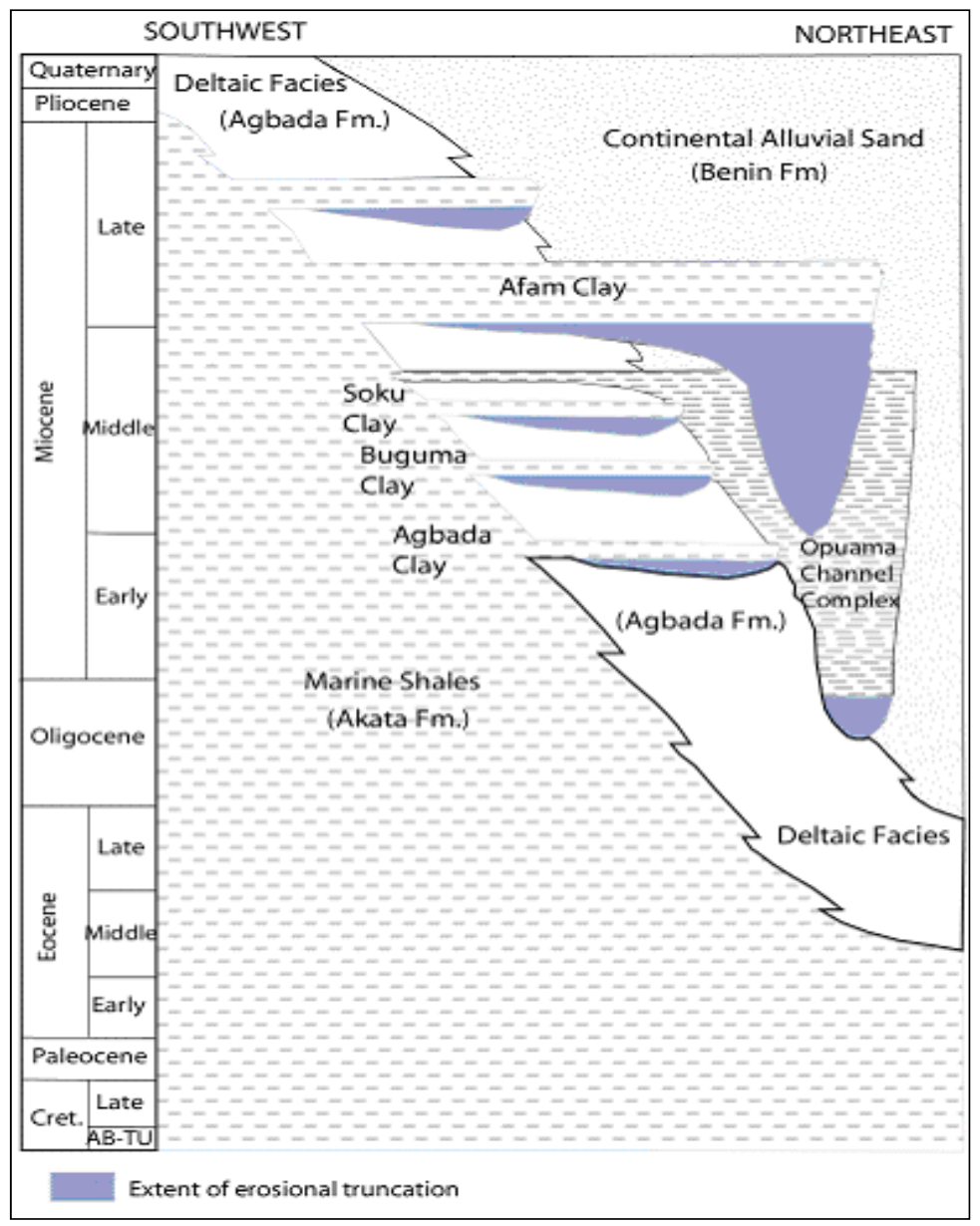

Figure 4. Stratigraphic column showing the three Formations of the Niger Delta, the Marine Akata shale, the paralic Agbada formation and the continental Benin sandstone. (Modified from Doust and Omatsola, 1990).

At the base of the system is the Akata Formation, a sequence of planktonic foraminifera rich undercompacted transgressive Paleocene-to-Holocene marine shales, clays, and silt. The Akata ranges in thickness from $2000 \mathrm{~m}(6600 \mathrm{ft})$ at the most distal part of the delta to $7000 \mathrm{~m}$ $(23,000 \mathrm{ft}$.) thick beneath the continental shelf (Doust and Omatsola, 1990). In the outer fold 
and thrust belts, the Akata Formation reaches $5000 \mathrm{~m}(16,400 \mathrm{ft}$.$) thick as a result of structural$ repetitions by thrust ramps and in the core of large detachment anticlines (Bilotti and Shaw, 2005). The Akata shales are typically undercompacted and frequently move either downward or laterally along the continental shelf, or in an upward diapiric motion along growth faults, in response to the lithostatic pressure of overlying sediment (Ekweozor and Daukoru, 1984). Lateral movements along the continental shelf result in thrusting in more outer bound regions of the Delta. The Akata Formation is conformably overlain by a paralic sequence of alternating Lower Eocene to Pleistocene sandstones and sand bodies with shale intercalations, which is known as the Agbada Formation (Doust and Omatsola, 1990). The Agbada Formation is more than $3500 \mathrm{~m}(11,500 \mathrm{ft}$.) thick and represents the actual deltaic portion of the sequence. This clastic sequence was accumulated in delta-front, delta-topset, and fluviodeltaic environments. The Agbada formation is highly faulted with assays of roll-over extension induced growth faults, compensation listric faults and high angle thrust faults depending on which belt of the Niger Delta you are in. Channel and basin-floor fan deposits in the Agbada Formation form the primary reservoirs in the Niger Delta. The Agbada Formation is in turn covered by the Benin Formation which consists of late Eocene to Holocene massive, porous, and unconsolidated freshwater bearing continental deposits, including alluvial and upper coastal-plain deposits that are up to $2000 \mathrm{~m}$ (6600 ft) thick (Avbovbo, 1978).

In the outer thrust belt, the Akata Formation lies upon oceanic crust and is diachronously overlain by deep-water channel complexes, debris flows, and shales of the Agbada Formation, which represent the sedimentary overburden of the deltaic succession (Maloney et al., 2010). The Benin Formation is absent in this belt (Maloney et. al., 2010). The Akata Formation and the shaly intercalations of the Agbada Formation are believed to be the source rocks of the Niger Delta while the paralic Agbada Formation constitutes the reservoir rock. It has also been suggested (Corredor et al, 2005) that the Akata Formation could contain some turbidite sands which could represent potential reservoirs in deep-water environments.

\subsection{The Extensional Province}

The development of the Niger Delta was initiated by rifting on the onshore portion of the West African Shield (Merki, 1972). The rifting is associated with the opening of the South Atlantic Ocean which began in the Late Jurassic and spanned through the Middle Cretaceous (Lehner and De Ruiter, 1977, as cited in Tuttle et al, 1999). Within the Delta, rifting had ceased by the Late Cretaceous. Thereafter, gravity induced tectonics became the primary deformational process and represent the key factor determining the structural style of the Extensional Province of the Niger Delta. Shale mobility induced internal deformation and occurred in response to two processes (Kulke, 1995, as cited in Tuttle et al, 1999). First, shale diapirs formed from loading of poorly compacted, over-pressured, prodelta and deltaslope shales of the basal Akata Formation by the advancing higher density delta-front paralic wedge of the Agbada Formation, and second, slope instability resulting from a lack of lateral, basinward, support for the under-compacted delta-slope Akata Formation. These movements initiated syn-sedimentary growth faults which compartmentalized the belts into 
fault blocks. As faulting advanced fault blocks rotated in fault planes and subsurface horizons formed roll-over anticlines. The resulting seaward extension of subsurface strata was often accommodated by landward dipping compensational listric faults. Other structures which formed include shale diapirs, collapsed growth fault crests, back-to-back features, and steeply dipping, closely spaced flank faults (Evamy et al, 1978). The Benin Formation was deposited only after the cessation of gravity induced tectonics and is unaffected by faulting.

\section{The Okari Field example: A gravitational shale tectonics field}

At the time of this study, the Okari Oil Field had six wells, four of the wells are vertical and the other two deviated. Though the wells had varying suites of logs, they generally possessed lithologic logs (Gamma Ray), porosity logs (sonic, density and neutron), resistivity logs (LLD and MSFL) and checkshot surveys. Available seismic data consisted of 401 inlines and 221 crosslines and a total of 88,621 post-stack seismic traces with a record length of 5 seconds, sampled at $4 \mathrm{~ms}$ interval and covering an area of about $56.5 \mathrm{sq} \mathrm{km}$.

Three of the wells, B1, B4 and B5 had encountered hydrocarbon in a stack of three horizons in a single roll-over anticlinal structure created by the rotation of an east-west trending fault block into the plane of a major structure building fault. The other three wells had turned out dry at the target horizon encountering water saturated sands and shales. It was understood that the variability of subsurface facies was more intricate than initially presumed. This is a known situation in the Niger Delta, the fast rate of sedimentation along the shelf edge and strong wave action are believed to have ensured rapid spacial variation in subsurface facies distribution patterns (Aminu and Olorunniwo, 2011). There was therefore a need to fully image the distribution of reservoir facies within the field to assist with further development and production.

\subsection{Methodology}

Our study of the field involved reservoir evaluation using well-logs, hydrocarbon saturated zones were identified and their respective petrophysical parameters were computed. Three horizons, $\mathrm{H1}, \mathrm{H} 2$ and $\mathrm{H} 3$, were found to be petroliferous. However, only the deepest horizon, H3, was considered prospective. It is a fairly shaly sand with average porosity of $27 \%$ and hydroarbon saturation of $77 \%$. Next we created a tectono-stratigraphic model of the field by mapping all three horizons and the field's cascade of intersecting faults (both growth and compensational listric faults). In this way we mapped a faulted anticlinal closure against a major structure building fault in the middle of the survey area. Thereafter, we used tri-variate crossplots to study rock-physics relations within the field and to provide a basis for calibration and interpretation of subsurface facies prediction. We then computed several seismic attributes, some of which include the instantanous amplitude, frequency and phase, $1^{\text {st }}$ and $2^{\text {nd }}$ derivative of the seismic trace, and various geometric seismic attributes. We experienced considerable difficulty deriving correlation between computed attributes and well information, and at obtaining geologically meaningful maps of subsurface 
property distribution. This may be due to one of two factors, (1) the seismic attribute - log relationships are often non-linear, and (2) the Niger Delta is a soft clastic basin with undercompacted subsurface formations, the seismic amplitude response in such cases are often weak and not well correlated to geology (Chopra and Marfurt, 2007). This necessitated that we impliment multi-attributes transforms to predict subsurface facies from the seismic response. We elected to use the multi-linear resgression transform and an artifcial neural network. The multi-linear transform attempts to derive a multi-variate linear relationship between seismic attributes and log derived petrophysical properties. If for a single attribute, the relationship between the target $\log L$ and the attribute $A$ is written as

$$
L=a+b A
$$

Where the coefficients $a$ and $b$ are obtained by minimizing the mean-squared prediction error:

$$
E^{2}=\frac{1}{N} \sum_{i=1}^{N}\left(L_{i}-a-b A_{i}\right)^{2}
$$

According to Hampson et al, 2001, the multivariate case for a single attribute is written as:

$$
L(t)=w_{0}+w_{1} A_{1}(t)+w_{2} A_{2}(t)+\ldots+w_{m} A_{m}(t)
$$

Where $L(t)$ represents the log sample, $A(t)$ are the corresponding seismic attributes and $w_{0} \ldots$ $w_{m}$ are the coefficients of the linear transform. If the log consists of $n$ samples then the equation is written as:

$$
\begin{aligned}
& L_{1}=w_{o}+w_{1} A_{11}+w_{2} A_{21}+\ldots+w_{m} A_{m 1} \\
& L_{2}=w_{o}+w_{1} A_{12}+w_{2} A_{22}+\ldots+w_{m} A_{m 2} \\
& L_{n}=w_{o}+w_{1} A_{1 n}+w_{2} A_{2 n}+\ldots+w_{m} A_{m n}
\end{aligned}
$$

Where $A_{i j}$ is the $j^{\text {th }}$ sample of the $i^{\text {th }}$ attribute (Hampson et al, 2001).

The neural network on the other hand is able to process multi-parameter and multidimensional data sets in a non-linear fashion via a learning process. The task of the neural network is to perform a non-linear mapping $k$ of a set of variables onto a target property,

$$
k: A_{m n} \rightarrow L_{m}
$$

In the case of log prediction from seismic data, the network reads a set of input predicting variables, a matrix $A_{m n}$ of seismic attributes and a set of desired output results, a vector $L m$ of $\log$ responses, computes its own output a vector $L_{m}$ ' of pseudo-log responses, computes the error vector $E_{m}\left(L_{m}-L_{m}{ }^{\prime}\right)$ and adjust its weights, a matrix $W_{i j}$ using a gradient descent algorithm in a direction as to minimize the disparity between the network's output and 
the desired target output. The neural network approximates a mapping function such that:

$$
L_{m}=\widehat{k}\left(W_{i j}, A_{m n}\right)+E_{m}
$$

where $\hat{k} \cong k$. The error given as:

$$
E\left(W_{i j}\right)=\frac{1}{2} \sum_{m}\left(L_{m}-L_{m}^{\prime}\right)^{2}
$$

and can be minimized using the back-propagation algorithm (Callan 1999, Liu and Liu, 1998). In practice a momentum factor is usually added to the gradient decent algorithm to speed up the search for an optimal solution and to prevent the network from getting caughtup in a local minimal. This process proceeds iteratively until the error bound is within preset acceptable limits. At this point the network is presumed to have trained adequately. Training is achieved with seismic attribute data and well information at well locations. The network is next implemented to predict pseudo-well-log responses throughout the field by being presented with seismic attribute data from beyond the wells.

\subsection{Discussion}

\subsubsection{Structure}

A total of 12 normal faults were mapped in the study area and are annotated F1 to F12 (Figure 5). Seven of the faults dip southward towards the sea while five are listric compensations for extentions within the fault blocks and dip landwards. These fault are gravity induced and are the result of the downwad and lateral response of the over-pressured mobile shales of the basal Akata Formation. Two of the faults F1 and F2 are major structure building growth faults which cut across the entire survey area and compartmentalize it into three east-west trending fault blocks which are downthrown and dip in the south-southwestward seaward direction (Figure 6). These faults appear to sole out as presumed (Corredor et al, 2005) at relatively shallow depths near the top of basal shale sequences. Fault blocks were created synchronously with sedimentation, this is seen from the relative thickening of subsurface formations on the downthrown side of the faults. Basal shales displaced by these fault blocks are believed to flow laterally along the continental shelve and the slips thereof tranferred through detachment structures in the basal Akata Formation onto thrust ramps and consumed by contractional folds in the deep-water fold and thrust belts (Bilotti and Shaw, 2005).

The back-to-back alternations of seaward and landward dipping normal faults resulted in the formation of horst and graben structures partcularly in the western end of the survey area (Figure 6). These horst and graben structures possibly resulted in the creation of mini depo-centres and are probably key factors controlling drainage and depositional patterns in the field. 
Contour closures against the major structure building F1 fault represent a faulted anticlinal structure juxtaposed against the fault. These structures form the majority of structural traps in the Niger Delta. Exploration wells in this field targeted this closure. Fault throw on the eastern arm of the anticlinal structure is much greater than on the western arm (Figure 7). This could indicate that there has been a relative clockwise rotation of the horizon along a crestal hinge line over the anticline lying orthogonal to the $F 1$ fault. This rotation appears to have added a sense of south easterly dip to the orientation of the fault block. This sense of dip could play a key role in determining drainaige and sediment deposition within the field.

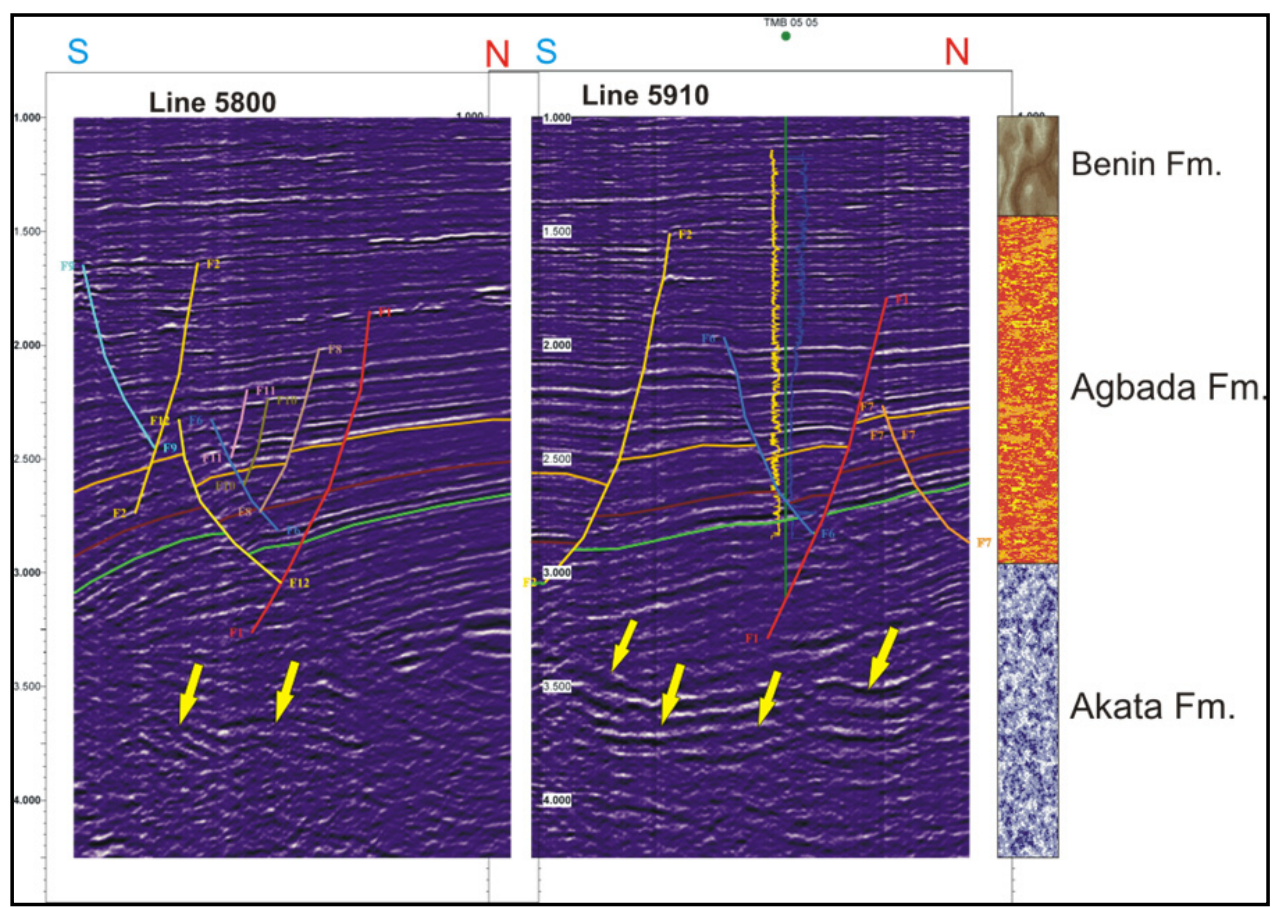

Figure 5. Interpreted seismic lines from the Okari field along with the litho-section. The target horizon in this study the $\mathrm{H3}$ is indicated in green. Growth faults affect only the paralic Agbada Fm. and compartmentalize the field into east-west trending blocks downthrown to the south. Horizon thickening on the downthrown blocks indicates that faulting was synchronous with sediment deposition. The Akata shales respond (as indicated by yellow arrow) by downward and seaward flowage due to the lithostatic pressure of the advancing paralic wedge. The Benin Formation were deposited after the ceasation of faulting and thus are not affected by faulting. 


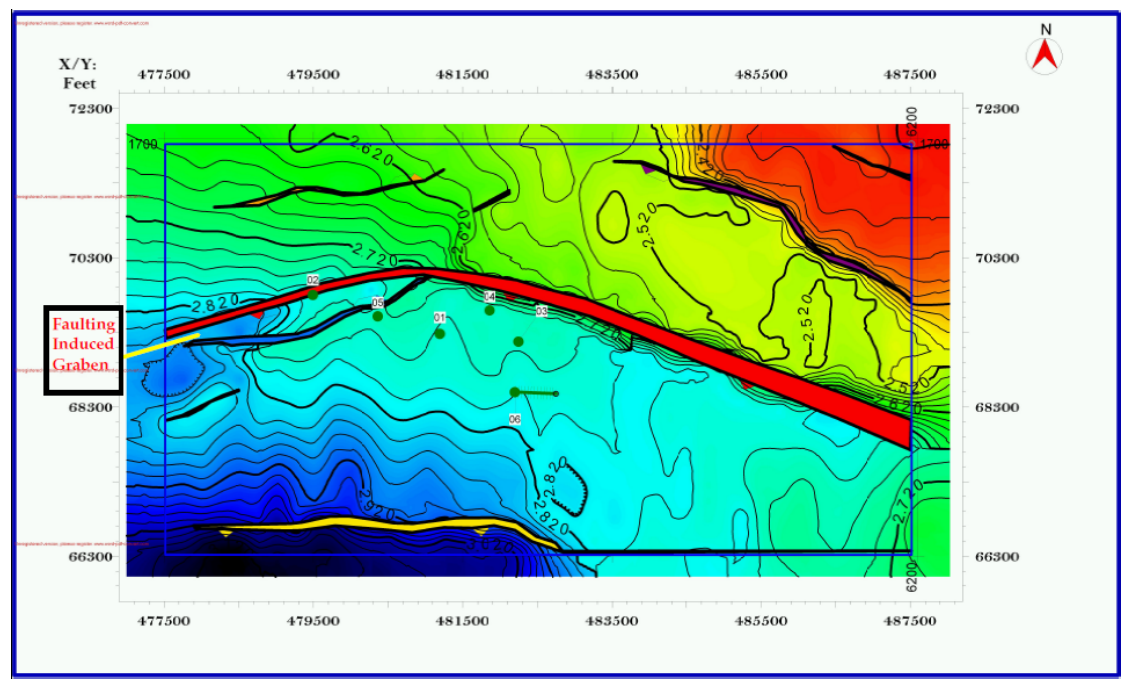

Figure 6. Horizon time map of the target $H 3$ horizon. Overall dip is in the south westerly direction with fault blocks trending roughly in the east-west direction. Seaward tensional stress is accomodated by landward dipping listric faulting to the west of the field thereby creating a graben structure which apparently played a key role in defining the paleo-drainage route on the horizon. Exploration wells targeted the contour closure against the major F1 fault (red).

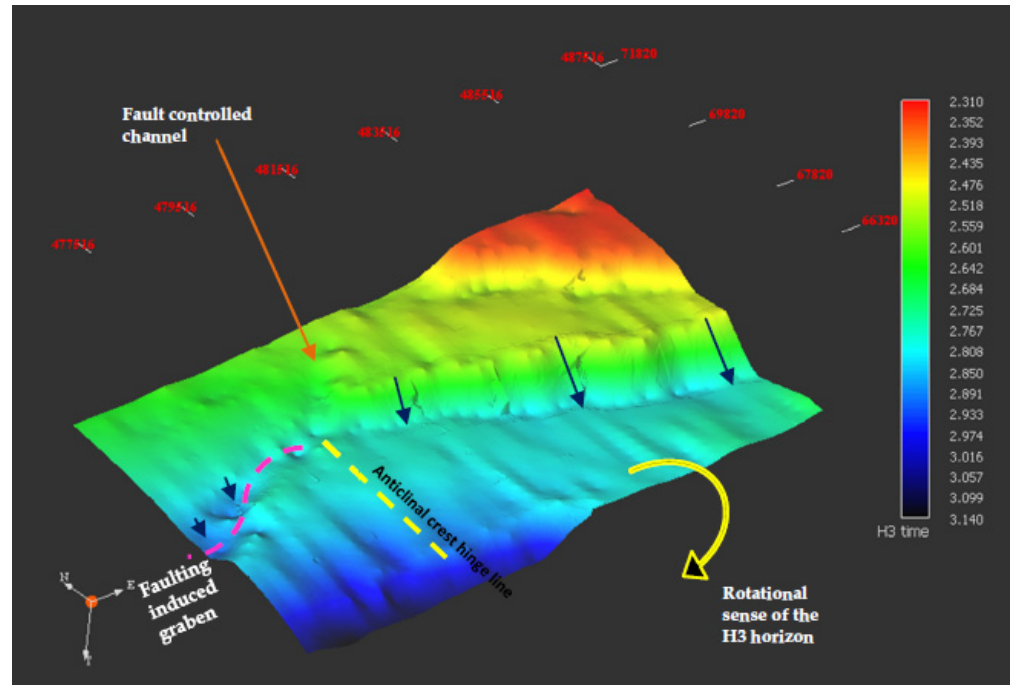

Figure 7. Annotated 3D view of the $H 3$ horizon. Fault throw (indicated in blue arrows) on the eastern arm of the major F1 fault is much greater than on the western arm. This appears to have been due to possible rotation of the fault block along a crestal line (yellow dashed line) over the anticlinal structure thereby giving the fault block a south easterly dip. A fault controlled channel is seen to trend in the south westerly direction and terminates against the $F 1$ fault. The fault induced graben structure has a fairly sinuous configuration. 
On the upthrown block of the F1 fault, a channel-like depression trending in the northeastsouthwest direction appears to terminate against the $F 1$ fault. This depression could have been a major path through which continentally derived detrites was supplied to the region of the anticlinal structure on the downthrown block of the $F 1$ fault.

\subsubsection{Cross Plots}

In cross-plots of $p$-wave impedance vs. porosity (Figure 8), we observed that $p$-wave impedance decreases with increase in porosity $(\theta)$, with lower-porosity sands generally having higher impedance values, likely a reflection of tighter grain packing. Porosity also increases with increase in shale content $\left(V_{\text {sh }}\right)$, with clean sands being associated with lower porosities than shaly units of corresponding densities. The shales of the Niger Delta are known to be under-compacted and over-pressured, and the platy nature of the shale minerals ensures they have high though ineffective porosities. The litho-facies are almost separable in two (along the blue line). Furthermore, high hydrocarbon saturation appears associated with lower-porosity dirty sands, with porosity in the range 23 to $27 \%$. The shales and water-bearing sands of the Okari Field appear, generally, to have higher porosities than hydrocarbon-saturated sands.

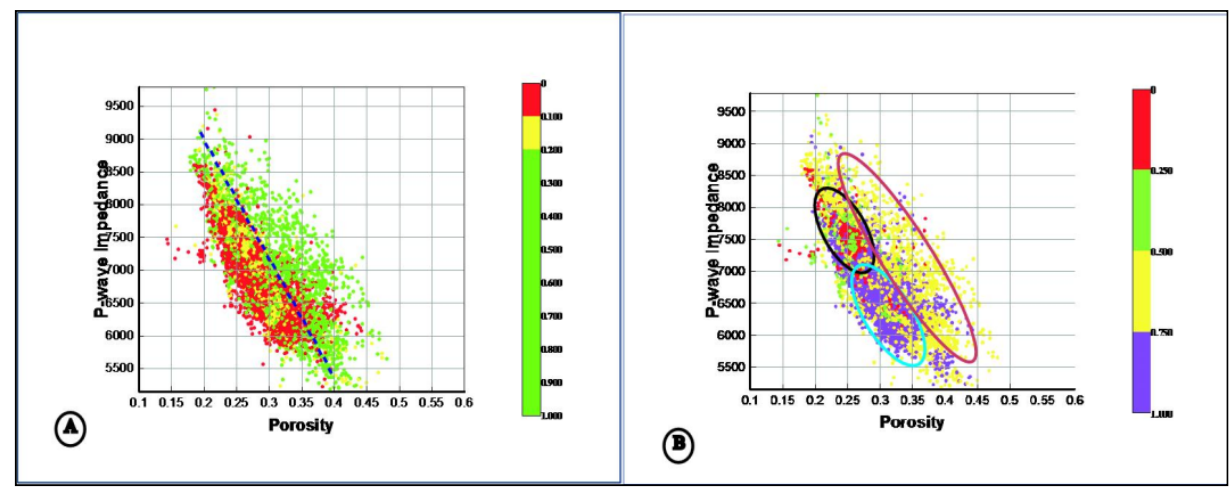

Figure 8. $P$-wave impedance vs. Porosity crossplots, (A) color coded in shale volume. Impedance decreases with porosity increase and shaly units generally possess high porosities. Between shales and sand facies, separation is almost possible along the dashed blue line, and (B) color coded in water saturation. Polygons represent subsuface facies; black for hydrocaron sands, light blue for water saturated sands and brown for shales. Hydrocarbon saturation is associated with lower porosity shaly sand facies.

These lower-porosity shaly reservoir sand units possibly benefitted from reduced hydrocarbon mobility due to the shale infilling of their pore spaces, while cleaner sands in the field may have lost their hydrocarbon saturations to invading brine as a result of their higher porosities and permeabilities, and consequent greater hydrocarbon mobility. Three distinct litho-facies are fairly well discriminated in this field; hydrocarbon sands associated with low relative porosities (23-27\%) and high $p$-wave impedance, water-saturated sands associated with medium to high porosities (25 - 35\%) and low impedance values, and shales associated 
with generally higher relative though ineffective porosities (30 - 42\%) and the entire spread of possible $p$-wave impedance values (from low through medium to high) in the field.

\subsubsection{Predicted litho-facies maps}

\subsubsection{Predicted Shale Volume Maps:}

Six seismic attributes; original trace, integral of the trace, average of the trace, average of instantaneous amplitude, and $1^{\text {st }}$ derivative and $2^{\text {nd }}$ derivative of the trace were multilinearly regressed against the target well logs (shale volume and porosity) in the vicinity of wells penetrating the $\mathrm{H} 3$ horizon. These attributes were selected for two major reasons; firstly, forward entry statistical regression of attributes against target well logs (porosity and shale volume) had turned up mainly amplitude-related attributes. Secondly, reviewed literature suggested that amplitude related seismic attributes have robust physical relationships to lithology and porosity (Banchs and Michelena, 2002; Dorrington and Link, 2004; Calderon and Castagna, 2005). The resulting multi-linear transforms were used to predict shale volume and porosity distributions for $\mathrm{H3}$ horizon. Employing the same set of seismic attributes used for the multi-linear regression, we implemented a total of 50 simulations for shale volume prediction over the $H 3$ horizon using a MultiLayered Feed-forward Back-propagation Neural Network (MFLN). Thereafter, we selected the network which produced the most geologically valid map and strictly honored well information.

The multi-linear regression of well log derived shale volume against the earlier mentioned six seismic attributes (statistics not shown here) turned up a correlation coefficient $R$ of 0.23 . The low statistical correlation underscores the difficulty in predicting lithology using linear regression algorithms. Mathematically, the chances of correctly imaging lithologic distribution over the horizon using multi-linear regression of these attributes will result only in a $23 \%$ correlation or similarity with actual shale volume distribution at the target horizon. Figure 9, is the result of this multi-linear attribute transform for the $H 3$ horizon. Our optimal neural network achieved 0.59 and 0.67 as validation and training correlation coefficients respectively. The validation coefficient is a significant improvement over the multivariate statistical regression coefficients $(0.23)$. As neural networks are able to implement non-linear mapping, they are better suited to codifying seismic-well-log relationships. The neural network predicted lithology map of the H3 horizon is shown in Figure 10.

The two predicted shale volume maps have stricking semblance in the horizon lithologic distribution and reservoir geometry and internal architecture they reveal. This engenders confidence in the robustness of the distribution so imaged. However, the neural network predicted shale volume distribution possesses greater detail compared to the multi-linear regression map. The maps show intricate details of lithologic variation both in the region of well control (reservoir region) and beyond. They reveal the subsurface paleo-drainage system and geologic situation of the field, one typical of the Niger Delta with several meandering sand-filled channels and sand bars especially in the southwest, north, and west of the field. The paleo-channels generally cross the study area in an east-west direction and possess shale volumes in the range of $15-20 \%$. This directional trend is most possibly 


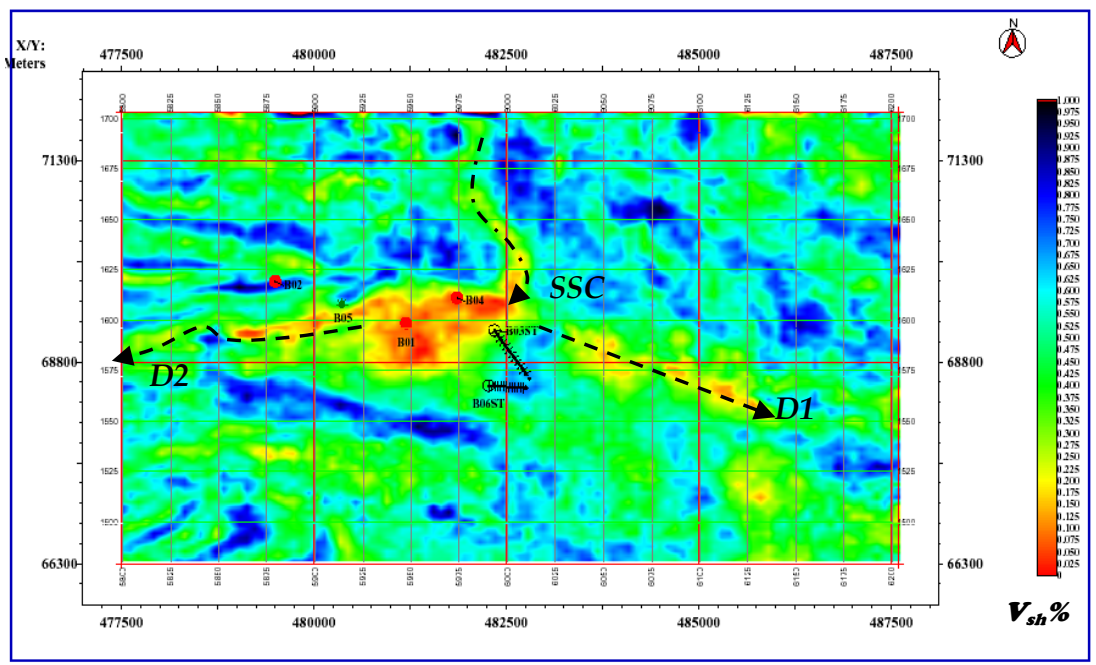

Figure 9. Multi-linear regression predicted shale volume map over the top of $H 3$ horizon. The sediment supply channel is a North-South trending sinuous channel SSC which terminates against the $F 1$ fault.In crossing the fault the sediments fan out while plunging into the rapidly emerging accomadation. D1 was possibly the initial drainage channel for the reservoir region but ceased altogether and the sand bodies became detached due to the onset of faulting induced channelization which created another path $D 2$ in the western region.

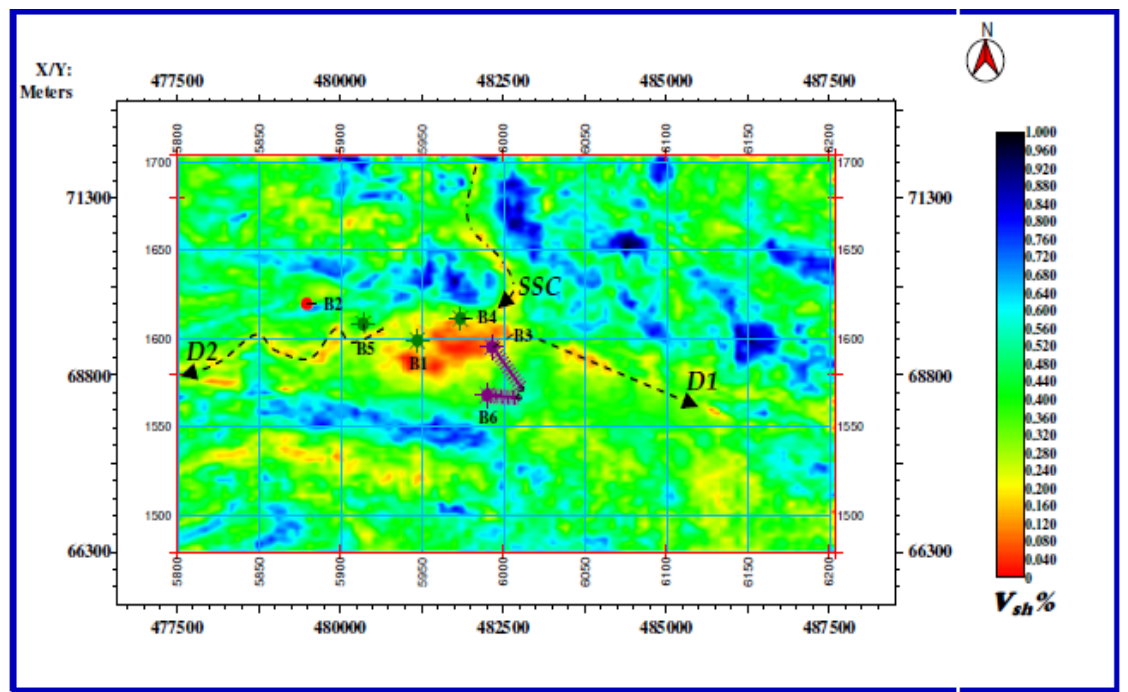

Figure 10. Predicted shale volume map over the top of $H 3$ horizon. The neural network prediction has high semblance with the result from regression but it provides greater detail in horizon property distribution and the reservoir geometry and internal architecture it delineates. The western D2 channel is seen to possess greater sinuosity than on the regression map. Lateral shale seals are predicted to the south of the reservoir. 
in response to dips on either sides of the anticlinal structure, that on the eastern arm resulting from possible clockwise rotation of the horizon in the plane of the F1 fault around an axis along the crest of the anticline and roughly orthogonal to the fault plane, while the accentuated dip on the western arm is largely the result of a fault induced graben structure. Channels in the western region demonstrate good lateral continuity while those in the eastern region are less continuous and appear separated from the reservoir. This is due in part to structural controls in form of grabens which guide channel flow in the western region. Channel sand bodies on the eastern arm were possibly separated from the reservoir as a result of horizon flexing during the formation of the roll-over anticline which hosts the known reservoir. It could also have been the result of the creation of considerably steeper dips on a portion of the western arm of the anticlinal structure due to the initiation of faulting controlled structural constraints (graben and half graben structures). The channel through the eastern arm D1 was possibly the initial drainage path for the reservoir region, this was temporal and might have ceased entirely with the onset of extension induced listric faulting on the western arm of the anticline. The faulting in the western region apparently defined an alternative drainage $D 2$ path for this anticline. A high-quality sand-filled paleo-channel SSC, trending roughly north-south on the upthrown block of the $F 1$ fault and possibly turning northwest above the reservoir region is imaged on both maps. This channel appears to have been the source of sediment fill for the reservoir region. In crossing the growth fault from north to south, the sediment load transported by the channel fanned out while plunging into the transient depo-center created by the active faulting.

The delineated reservoir is an oblate fan which coincides with the position of the structural closure on Figure 6 . The sand distribution within the reservoir region indicates that clean reservoir sands are interspersed with shaly sand units. Initial deposits were possibly reowrked by strong wave acton. These shaly-sand units serve to compartmentalize the reservoir and may act as flow barriers to hydrocarbons present and preclude communication between the segments of the reservior. Extensive lateral shales are predicted to the south and southeast of the reservoir. Coupled with the growth fault north of the reservoir, this possibly indicates reasonable lateral sealing mechanisms. Hydrocarbonbearing wells (B1, B4 and B5) penetrated clean to fairly shaly sands with shale volume in the range $15-20 \%$ at the target horizon while wells $B 2, B 3$, and $B 6$, penetrated shaly sands/shales. This result is in keeping with well information for the H3 horizon. It is nearly possible to trace out the outline of the major structure building F1 fault from the maps.

\subsubsection{Predicted Porosity Maps}

The multi-linear regression of well log derived porosity against the same seismic attributes set used for shale volume prediction (statistics also not shown) turned up a correlation coefficient $R$ of 0.43 . The correlation coefficient is considerably higher than that obtained for shale volume. This implies that it is easier to predict porosity from amplitude based seismic attributes using multi-linear regression than predicting lithology. Lithology index parameters such as grain shape index, minerology and 
platiness, to mention but a few, have more intricate relationships to the seismic amplitude response than coresponding determinants of porosity such as cementation and compaction. The predicted porosity map is shown in Figure 11. A neural network with the same network architecture and configuration as that used for predicting shale volume was trained using the same set of attributes viz. sample number, original trace, integral of trace, average of trace, average instantaneous amplitude, $1^{\text {st }}$ derivative and $2^{\text {nd }}$ derivative to predict porosity over $H 3$ horizon. Twenty-five (25) simulations of the neural network were run and the networks satisfying the two earlier mentioned criteria were selected. The most geologically valid map, which honored well information and correlated well with $\log$ information, was selected.

Figure 12 is the predicted porosity map over the $H 3$ horizon. The validation and training correlations for this network were 0.60 and 0.78 respectively. Though the training correlation in much higher than that for shale volume prediction, the validation correlation is hardly better. The validation correlation coefficient indicates the ability of a trained network to generalize on fresh data sets and is the true measure of the robustness of the prediction accuracy of a neural network. The minimal difference between the validation correlations for shale volume prediction and porosity prediction indicates that unlike the multi-linear regression transform, neural networks have almost no difficulty codifying the relationship between seismic attributes and either of well derived shale volume or porosity. This capability is no doubt due to their ability to perform non-linear multi-variate mapping in complex data spaces.

As with the case of shale volume prediction, there is striking semblance in the imaged reservoir architecture and horizon facies distribution revealed by the porosity maps predicted by both the multi-linear regression and the neural network. However, the neural network map provides higher resolution and images greater details of poro-facies variation both within the reservoir and beyond. The reservoir appears to be a fragmented lobe system with lower porosity facies (likely hydrocarbon bearing) interspaced with medium porosity facies (likely water bearing sands and or shales as indicated rockphysics cross-plots). This compartmentalization could be due to the re-working of the initial deposits by strong wave action. Key stratigraphic features imaged on the predicted shale volume maps such as the north-south trending paleo-channel and the eastern and western channels which drained the reservoir region are indicated as sinuous low porosity facies. The maps also indicate that the hydrocarbon-bearing wells penetrate lower porosity (20 - 27\% porosity) sands in the reservoir region. Rock-physics studies earlier discussed showed that hydrocarbon sands in the study area are associated with lower porosities compared to water saturated sands and shales. The maps also locate the non-hydrocarbon-wells in regions of relatively higher porosities (porosity greater than $32 \%$ ) indicating that they penetrate either water saturated sands or shales at the target horizon. The reservoir is bounded to the south by high porosity lithologies which represent shales, indicating again that the reservoir is surrounded by sufficient lateral shale seals to the south and the F1 fault to the north. 


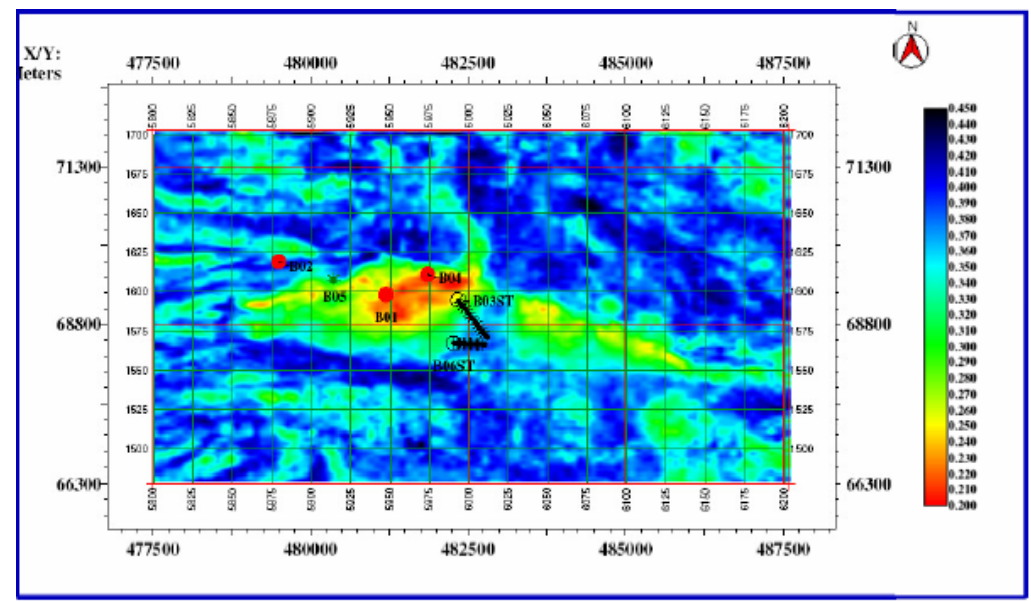

Figure 11. Multi-linear regression predicted porosity map over the top of $H 3$ horizon. Hydrocarbon wells are indicated to have penetrated lower porosity facies while dry wells encountered higher porosity facies (shales) at the target horizon. Earlier imaged channel features (SSC, D1 and D2) possess low to medium porosities in keeping with earlier crossplot results. The reservoir appears as an oblate fan.

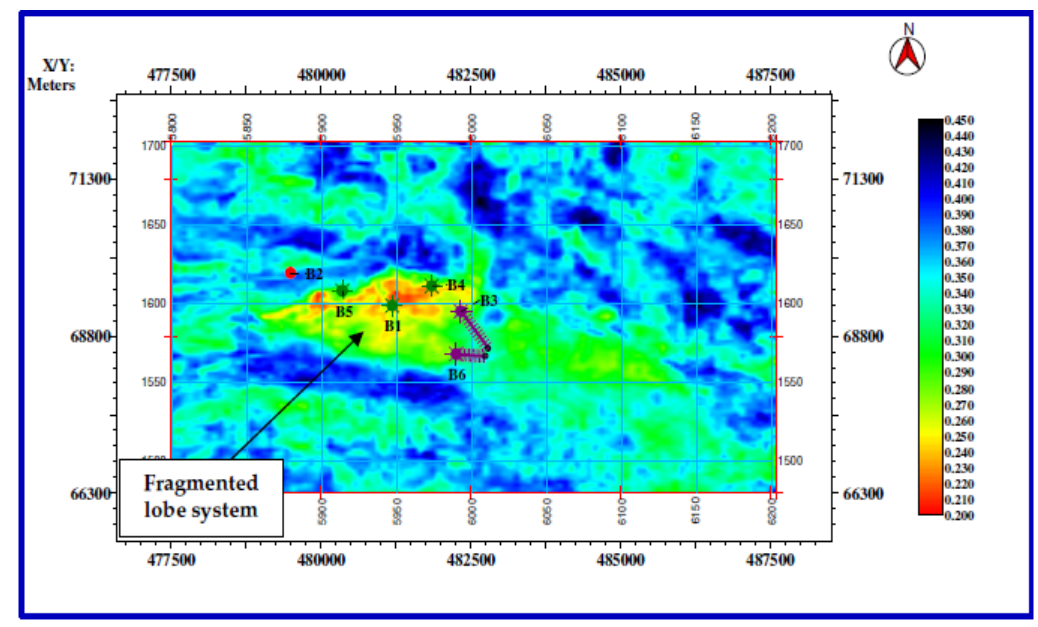

Figure 12. Neural network predicted porosity map over the top of $H 3$ horizon. The reservoir is a fragmented lobe system with low porosity facies (hydrocarbon sands) interspaced with medium porosity facies (water saturated sands), possibly a result of later re-working of sediments by strong wave action.

\section{Conclusion}

In this chapter, we have presented our attempt at unravelling the paleo-geomorphic settings of the Okari Oil field, a classical example from the extentional province of the Niger Delta. We employed conventional seismic interpretation techniques to build a tectono-stratigraphic model of the Field and to determine key factors which have contributed to and continue to 
define the development of this province of the Delta. We have further implemented advanced characterization techniques to image details of facies distribution within the field and further appreciate the effects of major factors on field evolution. Key factors affecting field evolution appear to have been the onset of regional seaward dipping syn-depositional growth faults and the accomodation of resultant extensions by landward dipping compensational listric faults. This resulted in rapid creation of accommodation in the form of mini depo-belts into which continentally derived detritus plunged. In traversing these growth faults the deposits fanned out as mini-deltaic fans which were possibly latter reworked and fragmented by strong wave action. Fault block rotation possibly played an important part in defining drainage paths but appear to have been overridden by the subsequent creation of graben structures by compensational faults. Paleo-geomorphic elements in the field include meandering channels, detached sand bars and a fragmented lobe system. Favorable reservoir facies are to be found in low-tomedium porosity shaly sands units.

\section{Author details}

Muslim B. Aminu

Adekunle Ajasin University, Akungba-Akoko, Nigeria

Moses O. Olorunniwo

Obafemi Awolowo University, Ile-Ife, Nigeria

\section{References}

Aminu, M. B., and Olorunniwo, M. A. (2011). Reservoir characterization and paleostratigraphic imaging over the Okari Field, Niger Delta, using neural networks. Leading Edge, v.30, no. 6, pp. 650-655.

Avbovbo, A.A. (1978). Tertiary lithostratigraphy of Niger delta. American Association of Petroleum Geologist Bulletin, v. 62, pp. 295-306.

Banchs, R. E. and Michelena, R, J. (2002). From 3D seismic attributes to pseudo well-log volumes using neural networks: Practical considerations. The Leading Edge, v.21, no. 10, pp. 996-1001.

Bilotti, F., and . Shaw, J. H. (2005). Deep-water Niger Delta fold and thrust belt modeled as a critical-taper wedge: The influence of elevated basal fluid pressure on structural styles. AAPG Bulletin, v. 89, no. 11, pp. 1475-1491.

Burke, K. (1972). Longshore drift, submarine canyons and submarine fans in development of Niger delta: American Association of Petroleum Geologist Bulletin, v.56, pp. 1975- 1983.

Calderon, J. E. and Castagna, J. (2005). Porosity and Lithologic Estimation Using Rock Physics and Multiattribute Transforms In the Balcon Field, Columbia-South America. Expanded Abstracts, $75^{\text {th }}$ SEG Annual International Meeting, pp. 444-447.

Callan, R. (1999). The Essence of Neural Networks. Prentice Hall Europe. P. 232.

Chopra, S., and Marfurt, K. (2007). Curvature attribute applications to 3D surface seismic data. The Leading Edge, v. 26, no. 4, pp. 404-414. 
Corredor, F., Shaw, J. H., and Bilotti, F., (2005). Structural styles in the deepwater fold and thrust belts of the Niger Delta: American Association of Petroleum Geologist Bulletin, v. 89 , no. 6 , pp. $753-780$.

Dorrington, K. P. and Link, C. A. (2004). Genetic-algorithm/ neural network approach to seismic attribute selection for well-log prediction. Geophysics, v. 69, no. 1, pp. 212- 221.

Doust, H. and Omatsola, E. (1990). Niger Delta, in J. D. Edwards, and P.A. Santogrossi, eds. Divergent / passive margins basins: American Association of Petroleum Geologist Memoir 48, pp. 201-238.

Dunlap, D. B., Wood, L. J., Weisenberger, C., and Jabour, H. (2010). Seismic geomorphology of offshore Morocco's east margin, Safi Haute Mer area. American Association of Petroleum Geologist Bulletin, v. 94, no. 5, pp. 615-642.

Ekweozor, C. M. and Daukoru, E. M. (1984). Petroleum source bed evaluation of Tertiary Niger Delta. American Association of Petroleum Geologists Bulletin, v. 70, pp.48-55.

Evamy, B.D., Harem boure, J., Knaap, P., Molloy, F. A. and Rowlands, P.H. (1978). Hydrocarbon Habitat of Tertiary Niger Delta, American Association of Petroleum Geologist Bulletin, v. 62, pp. 1-39.

Frankl, E. J. and Cordry, E. A. (1967). The Niger Delta oil Province: Recent development, onshore and offshore. Mexico City. Seventh World Petroleum Congress Proceedings v. 2, pp. 195-209.

Hampson, D. P., Schuelke, J. S. and Quirein, J. A. (2001). Use of multiattribute transforms to predict log properties from seismic data. Geophysics, v. 66, no. 1, pp. 220-236.

Liu, Z. and Liu, J., (1998): Seismic-controlled nonlinear extrapolation of well parameters using neural networks. Geophysics, v. 63, no. 6, pp. 2035-2041.

Maloney, D., Davies, R., Imber, J., Higgins, S., and King, S. (2010). New insights into deformation mechanisms in the gravitationally driven Niger Delta deep-water fold and thrust belt. American Association of Petroleum Geologist Bulletin, v. 94, no. 9. pp. 14011424.

Merki, P. J., (1972). Structural Geology of the Cenozoic Niger Delta. In: Dessauvagie, T. F. J. and Whiteman, A. J. (eds.), African Geology, University of lbadan Press, Nigeria, pp. 635-646.

Murat, R.C., (1970). Stratigraphy and Paleogeography of the Cretaceous and lower Tertiary in southern Nigeria, in $1^{\text {st }}$ Conference on African Geology Proceedings, Ibadan University Press, pp. 251-266.

Short, K. C. and Stauble, A. J. (1967). Outline of geology of Niger Delta. American Association of Petroleum Geologist Bulletin, v.51, pp. 761-799.

Tuttle, M. L. W., Charpentier, R. R., and Brownfield, M. E. (1999). The Niger Delta Petroleum System: Niger Delta Province, Nigeria, Cameroon, and Equatorial Guinea, Africa. United States Geological Survey, Open-File Report 99-50-H, P. 65.

Weber, K. J. and Daukoru, E. (1975). Petroleum Geology of the Niger Delta, Tokyo. 9 ${ }^{\text {th }}$ World Petroleum Congress Proceedings, v.2, pp. 209-211.

Whiteman, A. (1982). Nigeria - Its petroleum geology, resources and potential, London, Graham and Trotman, P. 394.

Wu, S., and A. W. Bally. (2000). Slope tectonics - Comparisons and contrasts of structural styles of salt and shale tectonics of the northern Gulf of Mexico with shale tectonics of offshore Nigeria in Gulf of Guinea, in W. Mohriak and M. Talwani, eds., Atlantic rifts and continental margins: Washington, D.C., American Geophysical Union, pp. 151-172. 